\title{
Comparative Economic Analysis of Active and Inactive Water User's Association in Rural Villages of Tamilnadu, India
}

\author{
B. Anuradha,*V. Mohan, R. Jaya Bharathi, \\ B. Saranya and M. Tamilselvi \\ Department of Civil Engineering, Madha Engineering College, \\ Kundrathur, Chennai, India
}

\begin{abstract}
In Tamilnadu state of India, tank irrigation system plays a very important part as they account for nearly one-third of the irrigation extent. The rainfed tank sector has traditionally been an important mainstay of Tamilnadu rural economy. In the years following independence, the performance of the sector declined for a number of economic and institutional reasons one among the predominant is inactive Water user's Association (WUA) in villages. WUA is a group of water users, such as irrigation, who pool their financial, technical, material and human resources for the operation and maintenance of a water system. Due to absence of WUA agricultural productivity is drastically reduced in terms of decreased cropping season and change in cropping pattern. Water scarcity from the sources (tank) due to asymmetrical usage is the main reason for less crop production. On the other side proper usage of available source of water by dynamic WUA gives best result in terms of economic return. Hence four tanks namely, Kolathur and Vellarai (Villages with inactive WUA) and Pillapakkam and Irumbedu (villages with active WUA) of Kancheepuram district, Sriperambathur taluk in Tamilnadu were selected for this study to probe the impact of inactive and active WUA on economic return. Primary data were collected through interview schedule and was analysed using investment appraisal technique. The result has revealed the Net present worth be positive, the B-C ratio be more than 1.5, the Internal rate of return be more than the opportunity cost of capital. This shows that all the three investments in tank rehabilitation are economicallv viable and higher for the villages acauire WUA. Hence it is necessarv to form a new WUA in the villages where it does'nt exist so far. Also WUA should be revived in a place where it is not functioning well.
\end{abstract}


Keywords: Agriculture, Economic analysis, Water User’s Association, Offfarm, Non-farm

\section{Introduction}

Though India's per capita availability is greater than "Water Stress Index", there are regions and states which fall into the category of "Water Scarce" territory, i.e., less than $1000 \mathrm{~m}^{3} /$ person/year. Being confined to a few monsoon months, rainfall behavior is highly erratic. This hydrological characteristic of the Indian monsoon necessitated the creation of storage facilities to hold the rainwater of the monsoon and utilize the same at a later date. With extraordinary engineering, managerial, and social skills, an extensive system of rainwater harvesting structures comprising tanks and ponds had been built and maintained by the people for centuries (Sakthivadivel 2006). South India has more tanks because of its geography, climate, and terrain situations (Vaidhyanayhan 2001). Most of the land lying between Western Ghats and the eastern coast let pass the intensive rainfall of the dependable south-west monsoon. But the north-east monsoon, which is less dependable, brings more rain over these areas. However, the north-east monsoon is often accompanied by cyclones and pours heavily in short spells. Unless this rain water is collected and stored, these areas will have acute water shortage and drought during the rest of the year. Hence tanks have come into existence in this part of the country in large numbers. The geological formation of South India is of hard granite gneisses, which helps reduce deep percolation from tanks and ponds. This may be yet another reason for the existence for more tanks in southern peninsular India than in the north. The north-east monsoon is more active in the coastal districts of Tamil Nadu and Andhra Pradesh and they also have the maximum number of tanks. The southern states of Andhra Pradesh, Karrnataka, and Tamil Nadu put together have around 1,43,000 tanks, constituting nearly $50 \%$ of the tanks in India (Vaidyanathan 2001). Tamil Nadu accounts for about seventeen percent of all tanks in India.

There are 39,202 tanks in the state as per record. At the time of the first five-year plan thirty three percent of the irrigated area was under tanks. It is now only twenty two percent. The development of canal irrigation and growth of well irrigation contributed to a great extent to the decline in the tank irrigated area over the years (Janakarajan 2003). Realising the importance of tanks the south Indian states have started rehabilitating the tanks in mid 1980s under state funds as well as external assistance. The general belief is that tanks are in vicious cycle of "Poor maintenance decline in performance - Rehabilitation - Poor maintenance" (CWR 2000). In the strict sense, 'rehabilitation' has traditionally meant technical interventions aimed at restoring a system to its original design potential for performance (FAO 1997). The accumulating evidences globally (especially after 1980) indicate that restoration and rehabilitation of existing irrigation tanks by adopting appropriate methodology and institutional mechanism (community based/participatory irrigation management, water user associations, tank association) will generate rural economy and promote sustainable development, through empowerment and self reliance (Moli and Poyya 2007). Tank rehabilitation not only helps farmers also, but also improve livelihood of 
landless poor, women and other vulnerable groups (Sakthivadivel et al., 2005). Presence of active WUA is the strength of increased income through farming, nonfarming and off-farming activities.

\section{Methodology \\ Study Area}

Pillaipakkam village is located at latitude of $12^{\circ} 9^{\prime} \mathrm{N}$ and at longitude of $79^{\circ} 9^{\prime} \mathrm{E}$. The total village area is 322.60 hectares and consists of 342 households. The total irrigated land is 176.27 hectares and rain fed land is 146.33 hectares. The only source of irrigation for this village is tank (Pillaipakkam tank). The irrigation schemes are available in this village which is organized by the Water users association (WUA). There are 7sluice present in the tank of this village. Depth of water stored in the tank is about 4.04 meters.

Irumbedu village is located at latitude of $12^{\circ} 9^{\prime} \mathrm{N}$ and at longitude of $79^{\circ} 9^{\prime} \mathrm{E}$ with a total area of 161.11hectares. This village has only tank irrigation system (Irumbedu tank) and the length of the tank is 1950 meters. Water users association is active in this village. Total irrigated area is 76.97.5 hectares and rain fed land is 84.22.5 hectares. The soil type is black cotton soil. Total population of the village is 2100 . There are only three sluices present in the village tank.

Kolathur village is located at latitude of $12^{\circ} 9^{\prime} \mathrm{N}$ and at longitude of $79^{\circ} 9^{\prime} \mathrm{E}$. The total village area is $422.66 h e c t a r e s$ and consists of 451 households. The total irrigated land is 376.27 hectares and rain fed land is 68.41 hectares. The only source of irrigation for this village is tank (Kolathur big tank). The irrigation schemes are not available in this village, i.e., no Water users association (WUA) exists. There are four sluices present in the tank. Depth of water stored in the tank is about 3.55 meters.

Vellarai village is located at latitude of $12^{\circ} 9^{\prime} \mathrm{N}$ and at longitude of $80^{\circ} 0^{\prime} \mathrm{E}$ with a total area of 191.16 hectares. This village has only tank irrigation system (Vellarai tank) and the length of the tank is 1760 meters. Water users association was formed earlier and was not successfully functioned later due to various conflicts raised among the members. Total irrigated area is 94.42hectares and rain fed land is 14.27hectares. The soil type found here is clay. There are only three sluices present in the village tank.

Households of women and men farmers who owned at least one irrigated plot of land under the study villages command were taken into consideration. From the above mentioned households 120 respondents from all the four villages (30 from each village) were selected in a stratified sampling method. Stratification with sampling unit i.e. households was felt necessary and the households were divided into different strata i.e. size of the land holding, reach, and well owning status. In order to achieve the proposed objectives, combinations of qualitative and quantitative methods were used to gather information from 2006-2011. Though many questions were included in the interview schedule, other qualitative methods such as stakeholders meetings and 
group discussions with certain categories of non-farm and off-farm involved villagers too added important information. Income incurred from 2006-2011 helps to calculate increased income through farming, non-farming and off-farming activities.

\section{Economic Measures}

Investment appraisal was carried out to find whether spending huge amount on the tank rehabilitation was economically viable in terms of net return. Using the discounted cash flow technique, net present worth, benefit-cost ratio, internal rate of return and pay back period were calculated for both the study villages. Economic measures evaluate the project worth by comparing the value of goods and services generated or conserved with the cost by assessing its effect on social welfare needs and viability. There are various undiscounted and discounted measures, which are available to evaluate the projects (Amarnath and Karthick Raja).

Benefit - Cost Ratio: Benefit - Cost Ratio (BCR) is the ratio obtained when the present worth of the benefit stream is divided by the present worth of the cost stream. The BCR implies that returns per rupee of investment. The criterion is that BCR should be greater than one for the project to be worth taking up.

$$
\begin{aligned}
& \mathrm{BCR}=\sum_{\mathrm{t}=1}^{\mathrm{n}} \frac{\mathrm{B}_{\mathrm{t}} /(1+\mathrm{i})^{\mathrm{t}}}{\mathrm{C}_{\mathrm{t}} /(1+\mathrm{i})^{\mathrm{t}}} \\
& \mathrm{t}=1,2 \ldots \ldots \ldots \ldots, \mathrm{n}
\end{aligned}
$$

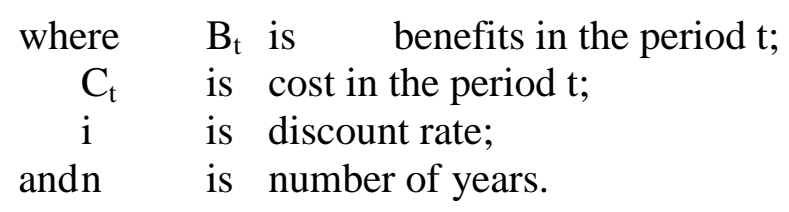

Net Present Worth: The most simple discounted cash flow measure of development project worth is the net present worth (NPW). This is simply the present worth of the incremental net benefit or incremental cash flow stream. It may also be computed by finding the difference between the present worth of the benefit stream less the present worth of the cost stream.

$$
\mathrm{NPW}=\sum_{\mathrm{t}=1}^{\mathrm{n}} \frac{\mathrm{B}_{\mathrm{t}}}{(1+\mathrm{i})^{\mathrm{t}}}-\sum_{\mathrm{t}=1}^{\mathrm{n}} \frac{\mathrm{C}_{\mathrm{t}}}{(1+\mathrm{i})^{\mathrm{t}}}
$$

In the case of the rural tank, it was rehabilitated in the years 2001-2002 and the benefit value was acquired for the year 2004-2005 through interviewing respondents. Hence, discounting factor was used to find the net present value. But in the peri-urban tank since the tank was rehabilitated in the years 1991-1992 and the benefit value was received for the year 2005-2006. Compounding factor was used to find the net present value. 
Internal Rate of Return: Internal Rate of Return (IRR) is the rate that makes the net present worth of the incremental net benefit stream or incremental cash flow equal zero. It is the maximum interest that a project could pay for the resources used if the project is to recover its investments and operating costs and still break-even.

$$
\mathrm{IRR}=\mathrm{LDR}+(\mathrm{HDR}-\mathrm{LDR})\left[\frac{\mathrm{NPW} \text { at LDR }}{\text { Sum of NPW at HDR and LDR }}\right]
$$

where LDR and HDR are respectively the lower and higher discount rates. The criterion is to select the project with IRR greater than the opportunity cost of capital or bank interest rate.

Pay back period: Pay back period is defined as the length of time required for the stream of cash proceeds produced by an investment to equal the original cash outlay required by the investments.

\section{Results and Discussions}

The literature on income diversification is thwarted with definitional problems and inconsistencies. Here 'non-farm' refers to those activities that are not primary agriculture or forestry or fisheries. However, non-farm does include trade or processing of agricultural products (even if, in the case of micro-processing activities, they take place on the farm). Barrett and Reardon (2001) stress that this definition is sectoral, i.e. it follows the convention used in national accounting systems where a distinction is made between primary production, secondary (manufacturing) activities, and tertiary (service) activities. It does not matter where the activity takes place, at what scale or with what technology.

Table 1: Investment appraisal for farm, non-farm and off-farm activities in Pillapakkam and Irumbedu village where Water User's Association is active

\begin{tabular}{|c|c|c|c|c|c|}
\hline S.No. & Description & IRR \% & BCR & NPV (Rs.) & PBP (Years) \\
\hline 1 & Farming & 12.00 & 1.06 & $1,26,146$ & 3.30 \\
\hline 2 & Non-farming and off-farming & 12.35 & 1.38 & $5,23,000$ & 1.75 \\
\hline 3 & $\begin{array}{c}\text { Farming, non-farming } \\
\text { and off-farming }\end{array}$ & 13.46 & 2.67 & $60,17,735$ & 1.20 \\
\hline
\end{tabular}

Table 2: Investment appraisal for farm, non-farm and off-farm activities in Kolathur and Vellari village where Water User's Association is inactive

\begin{tabular}{|c|c|c|c|c|c|}
\hline S.No. & Description & IRR \% & BCR & NPV (Rs.) & PBP (Years) \\
\hline 1 & Farming & 10.00 & 0.89 & $1,16,053$ & 5.80 \\
\hline 2 & Non-farming and off-farming & 10.08 & 0.92 & $2,45,276$ & 3.40 \\
\hline 3 & $\begin{array}{c}\text { Farming, non-farming } \\
\text { and off-farming }\end{array}$ & 11.00 & 1.20 & $30,57,765$ & 2.90 \\
\hline
\end{tabular}


The term 'non-farm' should not be confused with 'off-farm'. The latter generally refers to activities undertaken away from the household's own farm and some authors (Ellis 1998) use it to refer exclusively to agricultural labouring on someone else's land, so 'off-farm' used in this sense would not fall within the normal definition of 'non-farm'. Economically better endowed groups could benefit more from the farming to non-farming transformation as compared to the less endowed groups like landless labourers and marginal farmers. This crucial linkage between asset ownership and the economic potential for income and employment diversification is an important point that needs to be kept in mind while evaluating the impact of rural transformation on various rural groups in terms of occupational diversifications (Maria Saleph 1997). The impact of irrigation on the total incomes of marginal farmers, agricultural labours, artisans and other non- cultivating households was found to be even less; being statistically not significant. The impact was significantly felt only on cultivators other than the marginal (Nadkarni 1984). In view of increasing population pressure on agriculture, diminishing land frontiers, declining employment, elasticity in agriculture and urban organised manufacturing sector, higher incidence of unemployment and poverty, and excess supply of labour force etc., rural non agricultural activities are expected to play an important role in combating the problem of rural unemployment (Birada and Bagalkoti 2001).

Table 1 and 2 clearly elucidates that the investment appraisal values like B-C ratio, Internal rate of return, Net Present Value and Pay Back Period of farming alone, combination of non-farming and off-farming and all together are very less in case of Kolathur and Vellari tank. Reason behind this is absence of Water User's Association due to lack of cooperation among the farmers. Available water in the storage structure (tank) is not being utilized properly for irrigation. Hence they could cultivate very less extent of land by leaving the remaining land fallow. Most of the tail reach farmers cannot able to cultivate even one season paddy cultivation since water delivered through will not reach their land. Conveyance loss is very high due to improper maintenance of field channel. Weeding is not done regularly both in supply channel and field channel. Rotational water supply is not followed due to lack of leadership in the farming community. Participatory irrigation management is not seen in both the villages leads to very less economic return.

In the case of Pillapakkam and Irumbedu villages water users association is well maintained and the farmers are very cooperative for successful and sustainable Water User's Association. They have a well defined hierarchy like a chairman, secretary, treasurer, and a group of members for their association. They collect fund from the farmers with respect to the extent of their land holding (i.e Rs 100/acre/season). Collected amount is deposited in the Nationalised Bank and the interest amount is used for tank maintenance work. Supply channel is cleaned regularly before the monsoon starts. So that runoff water during rainfall will not go waste into the drainage channel. Also weeds grown in the field channel is removed frequently, so that the diverted water from the sluice will reach till tail end land after irrigating head and middle reaches. Also farmers are encouraged to debit money from the association at meager interest rate when they are in need of to purchase fertilizer or pesticide. Hence crop failure due to inadequate nourishment and pest problem could be avoided. 
Therefore the increased agricultural productivity helped those villages to achieve good return in terms of economic benefits.

\section{Conclusion}

Tanks in the Indian context are inextricably linked to the socio-economic aspects of rural communities especially and are considered an indispensable infrastructure of each and every village for sustaining the socio ecological balance. The tank system, which have been developed ingeniously over a period of several centuries have provided insulation from recurring droughts and floods and vagaries of monsoon, and provided the much needed livelihood avenue to the marginal and poor people living in the fragile semi-arid tropics. Water user's Association (WUA) in villages. WUA is a group of water users, such as irrigation, who pool their financial, technical, material and human resources for the operation and maintenance of a water system. Due to absence of WUA agricultural productivity is drastically reduced in terms of decreased cropping season and change in cropping pattern. Water scarcity from the sources (tank) due to irregular usage is the main reason for less crop production. The investment appraisal values like B-C ratio, Internal rate of return, Net Present Value and Pay Back Period of farming alone, combination of non-farming and off-farming and all together are very less in case of Kolathur and Vellari tank. But in the case of Pillapakkam and Irumbedu villages water users association is well maintained and the farmers are very cooperative for successful and sustainable Water User's Association. Hence The investment appraisal values ARE high and shows good return in terms of economic benefits So it is necessary to form a new WUA in the villages where it does'nt exist so far. Also WUA should be revived in a place where it is not functioning well.

\section{References}

[1] Amarnath.J.S., and Karthick Raja.P., (2006), “An Economic Analysis of Tank Rehabilitation in Madurai District of Tamil Nadu”,Agricultural Econimics Research Review, Vol 19, January-June, pp 187-194.

[2] Barrett C.B. and Reardon T. (2001), 'Asset, activity and income diversification among Africa agriculturalists: Some practical issues', In: Income Diversification and Livelihoods in Rural Africa: Cause and Consequence of Change, Special edition of Food Policy.

[3] Biradar R.R. and Bagalkoti S.T. (2001), 'Changing facts on Employment in Rural India; Emerging Issues and challenges', Indian Journal of Agricultural Economics', Vol. 56, No. 3.

[4] Centre for Water Resources (CWR) (2000), 'Monitoring and evaluation: Phase I and Phase II - Extension tank modernisation project with EEC assistance: Final Report', Vol. I and II, Anna University, Chennai, November.

[5] Ellis F. (1998), 'Survey article: household strategies and rural livelihood diversification', Journal of Development Studies, Vol. 35, No. 1, pp. 1-38. 
[6] FAO (1997), 'Modernisation of irrigation schemes: Past experiences and future options', Water reports \# 12, Bangkok: Food and Agriculture Organisation.

[7] Janakarajan.S (2003), "Need to Modernize the Tradition Changing role of Tanks in response to Scarcity and Variability", Market Development of Water \& Waste Technologies through Environmental Economics, 30th-31st October 2003, Delhi.

[8] Maria Saleph (1997), 'Occupational diversification among rural groups - A case study of rural transformation in Tamilnadu', Economic and Political Weekly, July 26.

[9] Moli Poyya G. and Guna B. (2007), 'Community based Tank rehabilitation/Irrigation management - Futuristic vision for the developing countries' Water: spatial dynamics, competitive claims and governance Reducing stress on the resource in urban, peri-urban and rural areas November 30-December 1.

[10] Nadkarni M.V. (1984), 'Irrigation and rural development - A sceptical view', Economic and Political Weekly, June, pp. A-67 - A-73.

[11] Narayanamoorthy A. (2001), 'Irrigation and rural poverty nexus: A statewise analysis’, Indian Journal of Agricultural Economics, Vol. 56, No.1, Jan.March.

[12] Sakthivadivel (2005), 'Tank water productivity in Palar basin', Report of the Fourth IWMI Tata Annual Partner's Meet, February

[13] Sakthivadivel.R., (2006), "Protocol for Tank Rehabilitation”, Rehabilitation and Management of Tanks in India, A Study of select states”, Asian Development Bank Publication.

[14] Vaidyanathan,A, (ed) 2001: Tanks of South India, Center for Science and Environment, New Delhi 